\title{
Preservation and Changes of Russian Culture from the Perspective of Film Language - Taking Attraction as an Example
}

\author{
Wenhan Yang \\ Heilongjiang University, Harbin 116085, Heilongjiang, China \\ Email: ywh20000702@163.com
}

\begin{abstract}
The changes of Russian literature and film language, to some extent, mirror the historical process of changes of Russian culture. In the history of cultural development in several centuries, Russia has critically absorbed the achievements of Eastern and Western civilizations on the premise of preserving its own cultural background, thus forming a Russian civilization with national characteristics. Taking Attraction as an example, this paper analyzes the preservation and changes of modern and contemporary Russian culture from the perspective of film language, so as to discover the changes of modern and contemporary Russian civilization.
\end{abstract}

Keywords: film language, Russian culture, preservation and change, Attraction

\section{Introduction}

Attraction is a science fiction based love affair film directed by Fyodor Bondarchuk with the love track of the heroine Yulya as the clue, and it depicted various contradictions and tensions in social life as the earth was collapsing. In the film, there are few descriptions of battles and invasions, but love, kinship, friendship and other elements are vigorously rendered with relatively slow pace. The doomsday soft science fiction film Attraction gives a large proportion on the discussion of human nature, conveying the director and screenwriter's unique world view and cosmology, and conveying the anti-war spiritual core.

\section{The preservation of Russian culture in the film language of Attraction}

\subsection{Preservation of love culture}

Love is the eternal theme of Russian films and world films. In modern and contemporary development of Russia film, in addition to the popular comedy, action movies, politics, social issues, ethics, love affair movies are distinctive embodiment of the Soviet films with spiritual culture, such as He's a Dragon(2016), Ekipazh (2016), Ice (2018), etc. Attraction is one of the most fascinating sci-fi films in the world for its unconventional humanism, which is primarily based on the love affair element.

At the end of the film, the alien Hijken and the heroine Yulya fall together in a hug in a battlefield filled with blood and smoke. Hijken finally exchanged his immortality for Yulya's resurrection, which is in contrast to the scene in the beginning when Yulya and Artyom carried on a clandestine love affair when the alien spaceship arrived. Attraction began with sensibility and ended with a cold, brutal narrative. Yulya looked up at the evening sky, her life has returned to peace, she experienced hurt and be hurt, love and be loved after the "fall" to watch the lover leave.

Non-Hollywood "individual heroism" science fiction certainly sparked a certain controversy in the treatment of its plot. However, the film retained the unique love affair culture gene of Russian films without taking a blind eye of the war, disaster, civilization invasion and other science fiction elements, which further enriched the plot, so that the audience could experience the "more important things" beyond the "eternal life", and the love in the war was more shocking.

\subsection{Preservation of friendship based culture}

Friendship is more important than money in the idea of many Russian people. There is a saying in Russia goes that: "More friends are more valuable than more money", which showed the importance of friendship to the Russian people ${ }^{[1]}$.

The intimate friendship failed to run through the film, but it was also highlighted from another angle of narrative. With the soft music from the headset of Yulya's best friend Svetlana, a devastating disaster befallen the earth. The music had not yet ended, the young lives were gone. It was not just the city itself that had collapsed in Attraction but also vulnerable lives. True friendship bear the blunt, Yulya and Artyom also began to crack.

It is worth mentioning that the character of Artyom was more comprehensively depicted than the heroine Yulya. He harbored a hatred attitude toward aliens, but his hatred seemed to stem only from Yulya's betrayal. He valued his friendship 
but incited riots in the name of mourning the death of his friend Ruslan. Even so, the deep friendship between Artyom and Ruslan was indeed the other side of his "evil of ignorance", mitigating the apocalyptic conflict and making Artyom's motives more human.

\subsection{Preservation of fighting culture}

Russia went through the Russian-French War, the October Revolution, the First World War and the Second World War, etc. Although there were victories and defeats, the Russian people never retreated. They always gave a head-on attack on the enemy,ringing great suffering to the enemy ${ }^{[2]}$. In the Soviet Union period, there were a large number of war based literature, film and television based works to describe the Russian brave and fearless fighting history.

Stalingrad (2013), another successful film directed by Fyodor Bondarchuk, depicted a thrilling battle between the German army and a detective team led by Captain Gromov to protect a 19-year-old girl named Kaga who refused to leave. If Stalingrad inherited the cultural connotation of a series of Soviet war films such as The Young Guard (1948), then Attraction would be regarded as the re-inheritance and development of his own creative idea again.

At the beginning of the film, the heroine Yulya, in order to avenge the death of her friend, regardless of her personal safety, always seek the opportunity to annihilate the aliens, even though she realized that she may lose her life because of it. The words and deeds of the Moscow people during the invasion of the aliens also reflected the Russian collective heroism and humanitarianism that were different from the American imperialist culture in the Russian films, which was also the preservation of the fighting culture spirit unique to the Soviet film language. While the flesh and blood of the Russian people were more vulnerable compared to the "armor of Vajrayas" of the aliens, they were touching enough to leave a strong impression.

\section{The change of Russian culture in the film language of Attraction}

\subsection{The changing culture of love affair}

In the final analysis, the theme connotation of love film was the search for the eternal proposition of love affairs. A large number of Russian love films in the Soviet Union period still enjoyed high artistic and aesthetic value and reference significance, such as Ryazanov's famous "love trilogy" - The Irony of Fate (1975), Office Romance (1977) and A Railway Station for Two (1983), Shore (1984) based on the novel by writer Yuri Bondarev, and The Barber of Siberia (1998), which began as a comedy but ended as a tragedy.

Under the long-term influence of national society and culture, love affairs in Soviet films was silent, obscure with low profile. It vividly and concretely depicted the emotional life of the Soviet people under the background of that era with ordinary realistic scenes and minimalist characters.

In Attraction, however, the expression of love culture had changed. Yulya, the heroine, was portrayed as a resolute, courageous, independent young woman who had the courage to pursue love. Although not approved by her father, Yulya was able to stick to her relationship with her boyfriend Artyome. When Yulya realized that she was in love with Hijken, she simply confessed to Artyome and entered a new chapter of love. It can be seen that the form of love culture in the current Russian film language was different from the past, but because of time vicissitude and the development of filming technology love story in the background elements gradually diversified, the spirit of female independence reflected in the novel also reflected the self-awakening of female consciousness in contemporary Russian society and even in the world. The current Russian love combined the enthusiasm and unrestrained of the West and the introversion and reserve of the East. Compared with the past, there has been a great change ${ }^{[3]}$.

\subsection{Changes in family culture}

In the family ethics bred by Russian national culture, the discourse right of parents was naturally authoritative. The traditional form of the Russian family was patriarchal, and the father's power can be involved in all aspects of the children's lives. Their fathers were despotic and rude; children were submissive and suspicious, repressing individuality-a profound manifestation of the Russian national character in its inherent family relationships.

However, in the past 20 years, the traditional patriarchy in modern and contemporary families is gradually losing its foundation of existence, parents and children added more radiance to each other, which also permeated the language of modern and contemporary Russian cinema, with a number of excellent works focusing on the ever-changing nuances of family relationships.

The film The Return (2003) that was shot by Andrei Zvyagintsev and won the Golden Lion Award at the Venice Film Festival, made an in-depth analysis of the change of family culture. The sudden return of his father, who had been absent for 
12 years, thrust his two grown sons, Andrei and Ivan, into a strong patriarchal rule. The father took the brothers on a vacation to a small island in northern Russia, but was always rude and dismissive of his sons. Conflicts and contradictions escalate, and the remaining balance is thrown out by the brothers' late "homing": the father is violent again, and Ivan climbs up the lighthouse in a rage, only to accidentally kill the pursuing father.

The father's death in the film was a metaphor for the transition of traditional "paternity", which was a changing point of family narrative in the film language, and also corresponded to the changing status of parent-child relationship in modern Russian families.

In the movie Attraction, Yulya called her grandmother by her first name, and she was pleasant to be called that. Although Yulya and her father Lebedev's contradictions run through the whole film, it was obvious that the father's various behaviors were not out of the authority of "paternity", but out of the worry and love for Yulya. When Yulya chose to fight and disobey, her father showed more helplessness and would compromise appropriately at the same time. Yulya took Hijken and told his father the relationship between them that under the guise of pregnant to get a pass and the father just pretended to scold, as a matter of fact, the father didn't give severe denouncement or punishment.

The change of Russian kinship culture stem from its integration into western democratic culture, shifting from the early obedience relationship to the current relationship of mutual help and mutual consultation ${ }^{[4]}$. This change has been realized in modern and contemporary Russian films.

\section{Changes of fighting culture}

Living in northern Eurasia, accustomed to the cold and wilderness, the Russian people developed from a nomadic people to this day, growing with slow but steady steps. The national history of Russia is the history of expansion and fighting. The cultural influence of the special geographical position and the long and hard war environment on Russia was reflected in its national character - pragmatic, tough, martial, unrestrained and melancholy.

The international order is undergoing profound and complex changes in a peaceful manner. The old order has collapsed, but new problems and contradictions continue to emerge as a result of the lingering power bullying, unilateralism and populism of individual countries.

The rigid and inviolable Russian nation will never forget its long and brilliant history of combat culture, which was the inexhaustible source of the construction of war plots in Russian literature and film and television. However, modern and contemporary writers and directors pay more attention to reflection of postwar and the nature of war culture than to battlefield conflict. The difference between Attraction and American war disaster films lied in that the film enjoyed a unique perspective of Russian humanistic feelings.

In brief, the valuable contents of Russian fighting culture are passed down from generation to generation, which will not disappear with the change of times, rather it will be remembered by the Russian nation in a new form ${ }^{[5]}$. The change of Russian war culture is also the epitome of the change and development of the world outlook and moral outlook of the Russian people.

\section{Conclusion}

Film, as a specific form of artistic expression created by culture, is one of the most vivid cultural communication media that is closest to the real social life. At the moment of watching a movie, we encounter the national culture of the shooting country, the width and breadth of human nature, and ourselves. Based on the film Attraction, this paper analyzes the preservation and change of Russian modern and contemporary culture from the perspective of film language, so that we can examine the change of Russian civilization in this period from multiple angles, so as to have a more comprehensive cognition of it.

\section{References}

[1] Oleg Marovitch, Andrei Zolotaryov. Attraction. Film Pictorial. 2018; (4): 56-57.

[2] Zhao Chunjing. Russian National Character from Russian and Soviet Films. Movie Literature. 2019; 625(4): 53-55.

[3] Liu Qing, Du Jun. Brief introduction to the characteristics of Russian films and their film and television language. Movie Literature. 2018; (6): 29-30.

[4] Feng Ling. The Casting of the Soul of the Nation - A Study of the National Spirit in Russian Ethnic Films. Humanities Forum. 2018; (1): 240-244.

[5] Yang Xinrong. Russian directors' different pursuit of "poetic films". Movie Literature. 2016; 655(10): 82-84. 